\title{
Benign cystic mesothelioma of the peritoneum: a case report and literature review
}

\author{
Hicham Elbouhaddouti, Abdesslam Bouassria, Ouadii Mouaqit, El Bachir Benjelloun, Abdelmalek Ousadden, \\ Khalid Mazaz and Khalid Ait Taleb
}

\begin{abstract}
Benign cystic mesothelioma of the peritoneum (BCM) is an uncommon lesion with some 130 cases reported since the first case described by Smith and Mennenmeyer in 1979. It is a rare intra abdominal tumor occurring predominantly in women of reproductive age. Due to the rarity of this tumor, similarity of patient presentation, and comparable features on imaging, the diagnosis of this pathology is difficult, and is based on histological findings. This tumor is known for local recurrence. It's agreed that surgery is the only effective treatment, but there are no evidence-based treatment strategies for BCM.
\end{abstract}

\section{Introduction}

Benign cystic mesothelioma of the peritoneum (BCM) is a rare intra abdominal tumor with a strong predilection for the peritoneum of pelvic organs. Symptoms are not specific, and the differential diagnosis is vast, including cystic lymphangioma, mucinous cystadenoma, cystic teratoma and pseudomyxoma retroperitonei. There are no evidence-based treatment strategies for BCM, and even if it is considered as a benign tumor, this tumor has a high local recurrence rate.

We report a new case of $\mathrm{BCM}$, which appeared as a surgical emergency.

\section{Case report}

A 71 year-old woman presented to the emergency department complaining of history of abdominal pain since 2 days accompanied by diarrhea. Four months prior to presentation, she noticed an increase in abdominal girth. Moreover, she developed occasional abdominal discomfort, which slowly increased frequency. The patient also developed symptoms of constipation and severe reflux which were not improved by taking laxatives and a proton pump inhibitor. Our patient was hemodynamically

\footnotetext{
* Correspondence: h.elbouhaddouti@yahoo.fr

Department of Surgery, School of Medicine and Pharmacy of Fez, Sidi Mohammed Ben Abdallah University, University hospital HASSAN II, BP: 1893, Km2.200, Route de Sidi Hrazem FEZ 30000, Morocco
}

stable with temperature at $37.9^{\circ} \mathrm{C}$, and blood pressure was 130/80 mmHg. Abdominal examination was marked by diffuse abdominal distension, and tenderness. Computed tomography (CT) scanning showed a large spherical multi-loculated cystic mass in the abdomen which was not-communicating to any abdomen viscera, occupying nearly the entire abdominal cavity, displacing the hole bowel (Figure 1). Furthermore, on CT scan, there was a strong suspicion of central tumor necrosis (Figure 2). Therefore, our patient was taken to operating theatre. Laparotomy was done. Intraoperative examination showed a cystic mass extending from the pelvis inferiorly to the liver. There was a significant peritoneal thickening, and a peritoneal effusion, with many cystic lesions that makes dissection and resection very difficult. The mass and some of the free-floating cysts were carefully harvested and removed for histological examination. Benign cystic mesothelioma was revealed in the pathology report.

Our patient made an excellent recovery, and she was discharged home after 6 days. Our patient was seen in out patient clinic at 1 month and 3 months. She had no functional complaints and kept a slight abdominal distension.

This study was performed according to the declaration of Helsinki and approved by the Local Ethical Committee.

\section{Discussion}

Benign cystic mesothelioma of the peritoneum (BCM) was described first by Mennenmeyer and Smith [1].

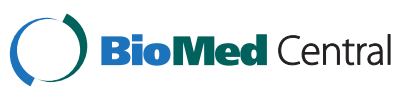

(c) 2013 Elbouhaddouti et al.; licensee BioMed Central Ltd. This is an open access article distributed under the terms of the Creative Commons Attribution License (http://creativecommons.org/licenses/by/2.0), which permits unrestricted use, distribution, and reproduction in any medium, provided the original work is properly cited. 


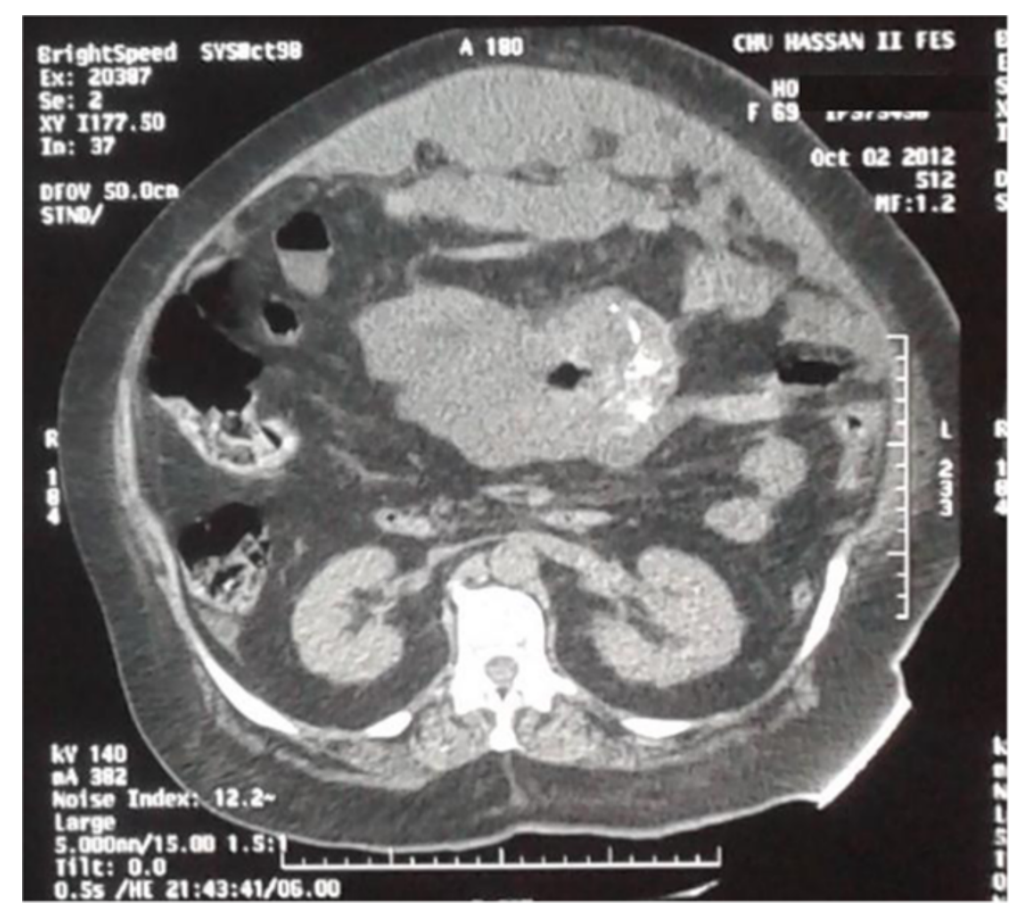

Figure 1 Large spherical multi-loculated cystic mass.

It's a rare pathological entity with about 130 cases reported in the literature [2,3] (Table 1). Several authors consider this tumor as benign [1,4], and it's prognosis is excellent [5]. There is only one reported death from $\mathrm{BCM}$ on the literature: Raafat and al. reported a case of a 14 years-old patient who had a subtotal resection of the abdominal mass, and died
12 years after refusing surgery for recurrence [6]. Indeed, BCM has a high local recurrence rate [7], and this recurrence rate is higher in women $(40-50 \%)$ than in men (33\%) [8]. The etiology remains unclear, but it is well known that many inciting factors may promote hyperplastic and neoplastic changes in mesothelial cells. The suggested provoking factors are

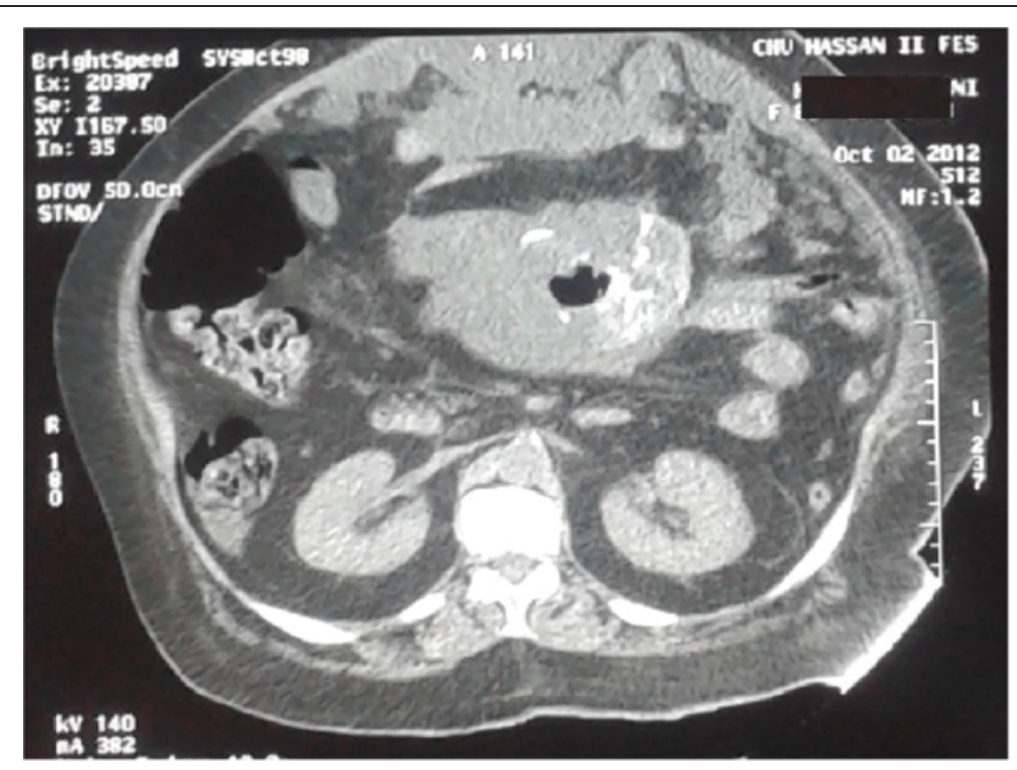

Figure 2 Suspicion of centro tumoral necrosis on CT scan. 
Table 1 Review of the literature

\begin{tabular}{|c|c|c|}
\hline Year & Authors & $\begin{array}{l}\text { Number } \\
\text { of cases }\end{array}$ \\
\hline 1982 & $\begin{array}{l}\text { Tasça and col. Benign peritoneal } \\
\text { mesothelioma. Hystopathology in a } \\
\text { case. Morphol Embryol; } 28 \text { (1): } 47-9\end{array}$ & 1 \\
\hline 1982 & $\begin{array}{l}\text { Katsube } Y \text { and col. Cystic mesothelioma } \\
\text { of the peritoneum: a report of } 5 \text { cases and } \\
\text { review of the literature. Cancer Oct 15; } 50 \text { (8) }\end{array}$ & 5 \\
\hline 1983 & $\begin{array}{l}\text { Schneider } V \text { and col. Benign cystic mesothelioma } \\
\text { involving the female genital tract: report of four } \\
\text { cases. Am J Obstet Gynecol; Feb 1; } 145 \text { (3) }\end{array}$ & 4 \\
\hline 1984 & $\begin{array}{l}\text { Philip G and col. Benign cystic mesothelioma. } \\
\text { Case reports. British journal of Obstetrics and } \\
\text { Gynaecology, Vol. 91, pp 932-938 }\end{array}$ & 2 \\
\hline 1987 & $\begin{array}{l}\text { Pastormalo M and col. Benign cystic } \\
\text { mesothelioma of the peritoneum. } \\
\text { Minerva Ginecologia, Mar } 39 \text { (3) }\end{array}$ & 1 \\
\hline 1989 & $\begin{array}{l}\text { Betta PG and col. Benign cystic mesothelioma } \\
\text { of the peritoneum. G Ital Oncol. Jan Mar; } 9 \text { (1) }\end{array}$ & 1 \\
\hline 1990 & $\begin{array}{l}\text { Hidvegi J and col. Benign cystic mesothelioma } \\
\text { of the peritoneum. Orv Hetil. Feb 4; } 131 \text { (5) }\end{array}$ & 1 \\
\hline 1990 & $\begin{array}{l}\text { Chen YC and col. Benign cystic mesothelioma } \\
\text { of the peritoneum: report of a case. } \\
\text { J Formos Med Assoc. Jun; } 89 \text { (6) }\end{array}$ & 1 \\
\hline 1991 & $\begin{array}{l}\text { Hidvegi J and col. Peritoneal benign cystic } \\
\text { mesothelioma. Pathol Res Pract. Jan; } 187 \text { (1) }\end{array}$ & 1 \\
\hline 1991 & $\begin{array}{l}\text { Pollack CV and col. Benign cystic mesothelioma } \\
\text { presenting as acute abdominal pain in a young } \\
\text { woman. J Emerg Med: } 9 \text { Suppl 1:21-5 }\end{array}$ & 1 \\
\hline 1994 & $\begin{array}{l}\text { Kyzer S and col. Benign cystic mesothelioma of } \\
\text { the peritoneum. Eur J Surg. May; } 160 \text { (5) }\end{array}$ & 1 \\
\hline 1995 & $\begin{array}{l}\text { Ricci F and col. Benign cystic mesothelioma in a } \\
\text { male patient: surgical treatment by the laparoscopic } \\
\text { route. Surg Laparosc endosc. Apr; } 5 \text { (2) }\end{array}$ & 1 \\
\hline 1995 & $\begin{array}{l}\text { Takenouchi Y and col. Report of a case of benign } \\
\text { cystic mesothelioma. Am J Gastroenterol; Jul } 90 \text { (7) }\end{array}$ & 1 \\
\hline 1996 & $\begin{array}{l}\text { Tomasini P and col. Benign peritoneal multicystic } \\
\text { mesothelioma. J Radiol; Jan } 77 \text { (1) }\end{array}$ & 1 \\
\hline 1996 & $\begin{array}{l}\text { Yaegachi } \mathrm{N} \text { and col. Multilocular peritoneal inclusion } \\
\text { cysts. J Obstet Gynaecol Res; Apr } 22 \text { (2) }\end{array}$ & 1 \\
\hline 1997 & $\begin{array}{l}\text { Cusatelli P and col. Benign cystic mesothelioma of the } \\
\text { peritoneum: a case report. Eur J Gynaecol Oncol. } 18 \text { (2) }\end{array}$ & 1 \\
\hline 1997 & $\begin{array}{l}\text { Van Der Klooster and Col. Successful catheter } \\
\text { drainage of recurrent benign multicystic mesothelioma } \\
\text { of the peritoneum. Neth J Med, Jun; } 50 \text { (6) }\end{array}$ & 1 \\
\hline 1998 & $\begin{array}{l}\text { Abino JF and col. Peritoneal benign polycystic } \\
\text { mesothelioma. Press Med, Apr 25; } 27 \text { (16) }\end{array}$ & 1 \\
\hline 1998 & $\begin{array}{l}\text { Letterie GS and col. The antiestrogen tamoxifen in } \\
\text { the treatment of recurrent benign cystic mesothelioma. } \\
\text { Gynecol Oncol, Jul; } 70 \text { (1) }\end{array}$ & 1 \\
\hline 1998 & $\begin{array}{l}\text { Kumar D and col. Benign cystic peritoneal mesothelioma } \\
\text { in a man. Indian J Gastroenterol, Oct-Dec; } 17 \text { (4) }\end{array}$ & 1 \\
\hline 1999 & $\begin{array}{l}\text { Keiri-Vassilatou E and col. Benign cystic mesothelioma } \\
\text { of the peritoneum an immunopathological study of } \\
\text { three cases. Eur J Gyneacol Oncol. } 20 \text { (4) }\end{array}$ & 3 \\
\hline 1999 & $\begin{array}{l}\text { Jovovic M and col. Multicystic mesothelioma of the } \\
\text { peritoneum. Vojnosanit Pregl. Mar-Apr; } 56 \text { (2) }\end{array}$ & 1 \\
\hline
\end{tabular}

Table 1 Review of the literature (Continued)

1999 Park BJ and col. Treatment of primary peritoneal mesothelioma by continuous hyperthermic peritoneal perfusion (CHPP). Ann Surg Oncol, Sep;6(6):582-90.

2001 Petrou G and Col. Benign cystic mesothelioma in a 60 year old woman after cholecystectomy. ANZ J Surg, Oct; 71 (10)

2002 Hafner M and Col. Giant Benign cystic mesothelioma: 1 a case report and review of the littérature. Eur J Gastroenterol Hepatol. 2002 Jan;14(1):77-80.

2002 Van ruth S and Col. Peritoneal Benign cystic 1 mesothelioma: a case report and review of the literature. Eur J Surg Oncol. 2002 Mar;28(2):192-5

2002 Adolph AJ and col. Benign multicystic mesothelioma: a 1 case report. J Obstet Gynaecol Can. 2002 Mar;24(3):246-7.

2002 Cavallaro A and col. Benign multicystic mesothelioma 1 of the peritoneum: a case report. Chir Ital. 2002 Jul-Aug;54(4):569-72

2003 Shawn RN and col. Benign cystic mesothelioma of the peritoneum: a clinicopathologic study of 17 cases and immunohistochemical analysis of estrogen and progesterone receptor status. Hum Pathol. 2003 Apr;34(4):369-74.

2003 Bruni R and col. Benign cystic mesothelioma with multiple recurrences: a clinical case. Chir Ital. 2003 Sep-Oct;55(5):757-60

2004 Varma R and Col. Multicystic benign mesothelioma of the peritoneum presenting as postmenopausal bleeding and a solitary pelvic cyst--a case report. Gynecol Oncol. 2004 Jan;92(1):334-6.

2004 Baeyens P and col. Benign cystic peritoneal mesothelioma. JBR-BTR. 2004 May-Jun;87(3):114-5

2005 Szöllósi A and col. Benign cystic mesothelioma, a rare tumor of the peritoneum. Magy Seb. 2005 Feb;58(1):35-7

2005 Urbańczyk K and col. Mesothelial inclusion cysts 6 (so-called benign cystic mesothelioma)-a clinicopathological analysis of six cases. Pol J Pathol. 2005;56(2):81-7.

2006 Svetlana M and col. Benign cystic mesothelioma of the peritoneum. Isr Med Assoc J. 2006 Jul;8(7):511-2

2006 Safioleas MC and col. Benign multicystic peritoneal New case mesothelioma: a case report and review of the literature. 1 Review: World J Gastroenterol. 2006 Sep 21;12(35):5739-42 130 cases

2007 Coskun A and col. Benign cystic mesothelioma 1 presenting as a huge pelvic mass--a case report. Eur J Gynaecol Oncol. 2006;27(6):621-2

2007 Saad S and col. Benign peritoneal multicystic mesothelioma diagnosed and treated by laparoscopic surgery. J Laparoendosc Adv Surg Tech A. 2007 Oct; 17(5):649-52

2008 Ashqar S and col. Benign mesothelioma of peritoneum presenting as a pelvic mass.J Coll Physicians Surg Pak. 2008 Nov; 18(11):723-5

2008 Chammakhi-Jemli C and col. Benign cystic mesothelioma 1 of the peritoneum. Tunis Med. 2008 Jun;86(6):626-8

2008 Stroescu and col. Recurrent benign cystic peritoneal 1 mesothelioma. Chirurgia (Bucur). 2008 Nov-Dec;103(6):715-8

2009 Uzum N and col. Benign multicystic peritoneal mesothelioma.Turk J Gastroenterol. 2009 Jun;20(2):138-41 


\section{Table 1 Review of the literature (Continued)}

\begin{tabular}{|c|c|c|}
\hline 2010 & $\begin{array}{l}\text { Limone A and col. Laparoscopic excision of a benign } \\
\text { peritoneal cystic mesothelioma. Arch Gynecol Obstet. } \\
2010 \text { Mar;281(3):577-8 }\end{array}$ & 1 \\
\hline 2010 & $\begin{array}{l}\text { Pitta } X \text { and col. Benign multicystic peritoneal } \\
\text { mesothelioma: a case report. J Med Case Rep. } \\
2010 \text { Nov 29:4:385 }\end{array}$ & 1 \\
\hline 2011 & $\begin{array}{l}\text { Akbayir O and col. Benign cystic mesothelioma: a case } \\
\text { series with one case complicated by pregnancy. } \\
\text { J Obstet Gynaecol Res. } 2011 \text { Aug;37(8):1126-31. }\end{array}$ & 3 \\
\hline 2012 & $\begin{array}{l}\text { Lari F and col. Benign multicystic peritoneal } \\
\text { mesothelioma. A case report. Recenti Prog Med. } \\
\text { 2012 Feb;103(2):66-8 }\end{array}$ & 1 \\
\hline 2012 & $\begin{array}{l}\text { Stojsic Z and col. Benign cystic mesothelioma of the } \\
\text { peritoneum in a male child.J Pediatr Surg. } \\
2012 \text { Oct: } 47(10): e 45-9\end{array}$ & 1 \\
\hline 2012 & $\begin{array}{l}\text { Khuri S and col. Benign cystic mesothelioma of the } \\
\text { peritoneum: a rare case and review of the literature. } \\
\text { Case Rep Oncol. } 2012 \text { Sep;5(3):667-70. }\end{array}$ & 1 \\
\hline 2013 & $\begin{array}{l}\text { Singh A and col. Multicystic peritoneal mesothelioma: } \\
\text { not always a benign disease.Singapore Med J. } \\
2013 \text { Apr;54(4):e76-8 }\end{array}$ & 1 \\
\hline
\end{tabular}

foreign fibres and dusts, inflammatory mediators, and mechanical injuries [9]. Proliferation and inward migration of peripheral mesothelial cells, proliferation and metaplasia of underlying connective tissue cells, and surface attachment and differentiation of free-floating mononuclear cells all have been postulated as the mechanism of mesothelial cell proliferation in pathological conditions [9]. This peritoneal lesion is characterized by the formation of multiple multilocular thin-walled cysts, which may form large intraabdominal masses [1]. The BCM affects women in $80 \%$ of cases, with an average age of 34 years [3]. The clinical presentation is unspecific: it is usually abdominal pain, increased abdominal girth and constipation. Physical examination revealed abdominal distension, abdominal tenderness or a palpable mass [10]. Imaging modalities that can be used include abdominal ultrasound (US), CT scan, or magnetic resonance imaging (MRI). They allow to visualize the lesion, but not to differentiate it from other cystic lesions of the peritoneum [11], especially lymphangiomas [9]. Laparoscopy remains the best diagnostic tool because it enables to perform biopsies and to establish the definitive diagnosis [12]. There are no evidence-based treatment strategies for BCM, but surgery, with complete enucleation of the cyst to prevent recurrence and possible malignant transformation remains the mainstay of treatment. However, some researchers advocate aggressive surgery followed by heated intraperitoneal chemotherapy (HIPEC) [12]. Indeed, for a long time, the treatment consist of full excision of the lesions (debulking surgery) [7]. Currently, some teams recommend aggressive surgery (extended peritonectomy) followed by HIPEC
$[3,13]$. Two series are available on the results of extended peritonectomy followed by HIPEC. In the first one [13], 5 patients were asymptomatic, and 4 showed no recurrence with a follow up between 6 and 69 months. In the second series [14], 5 patients were asymptomatic, and 2 had got recurrence, with a follow up between 3 and 102 months.

\section{Conclusion}

Benign cystic mesothelioma of the peritoneum (BCM) is a rare tumor with a high local recurrence rate. It requires optimal care in a specialized center especially as there is no evidence-based treatment strategies.

\section{Consent}

Written informed consent was obtained from the patient for publication of this Case report and any accompanying images.

\section{Competing interests}

All authors declare that they have no competing interests.

\section{Authors' contributions}

$E B H$ and $A B$ participated in writing the case report and revising the draft, $\mathrm{OM}, \mathrm{EB}, \mathrm{AO}, \mathrm{KM}$ and KAT participated in the follow up. All authors read and approved the final manuscript.

Received: 9 June 2013 Accepted: 6 October 2013

Published: 13 October 2013

\section{References}

1. Mennemeyer R, Smith M: Multicystic, peritoneal mesothelioma: a report with electron microscopy of a case mimicking intra-abdominal cystic hygroma (lymphangioma). Cancer 1979, 44:692-698.

2. Safioleas MC, Constantinos K, Michael S, Konstantinos G, Constantinos S, Alkiviadis K: Benign multicystic peritoneal mesothelioma: a case report and review of the literature. World J Gastroenterol 2006, 12(35):5739-5742.

3. González-Moreno S, Yan H, Alcorn KW, Sugarbaker PH: Malignant transformation of "benign" cystic mesothelioma of the peritoneum. J Surg Oncol 2002, 79:243-251.

4. Van Ruth S, Bronkhorst MWGA, Van Coeverden F, et al: Peritoneal benign cystic mesothelioma: a case report and review of literature. Eur J Surg Oncol 2002, 28:192-195.

5. Bhandarkar DS, Smith VJ, Evans DA, Taylor TV: Benign cystic peritoneal mesothelioma. J Clin Pathol 1993, 46:867-868.

6. Raafat $F$, Egan M: Benign cystic mesothelioma of peritoneum. Immunohistochemical and Ultrastructural features in a child. Paediatr Pathol 1988, 8:321-9.

7. Schwartz AT, Peycru E, Tardat JP, Dufau J, Jarry F, Durand-Dastes: Le mésothéliome kystique péritonéal: bénin ou malin ? J Chir 2008, 145:8.

8. Canty MD, Williams J, Volpe RJ, et al: Benign cystic mesothelioma in a male. Am J Gastroenterol 1990, 85:311-15.

9. Pelosil G, Zannonil M, Caprioli F, Faccincani L, Battistoni MG, Balercia G, Bontempinil L: Benign multicystic mesothelial proliferation of the peritoneum: Immunohistochemical and electron microscopical study of a case and review of the literature. Histol Histopath 1991, 6:575-583.

10. Vyas, et al: Mesothelioma as a rapidly developing giant abdominal cyst. World J Surg Oncol 2012, 10:277.

11. Yang DM, Jung DH, Kim H, Kim JH, Hwang HY: Retroperitoneal cystic masses: CT, clinical, and pathologic findings and literature review. Radio Graphics 2004, 24:1353-1365. 
12. Khuri SH, Assalia Y, Abboud A, Gilshtein W: Kluger benign cystic mesothelioma of the peritoneum: a rare case and review of the literature. Case Rep Oncol 2012, 5:667-670.

13. Sethna K, et al: Peritoneal cystic mesothelioma: a case series. Tumori 2003, 89:31-35.

14. Baratti $\mathrm{D}$, et al: Multicystic peritoneal mesothelioma treated by surgical cytoreduction and hyprerthermic intra peritoneal chemotherapy (HIPEC). vivo 2008, 22:137-157.

doi:10.1186/1749-7922-8-43

Cite this article as: Elbouhaddouti et al: Benign cystic mesothelioma of the peritoneum: a case report and literature review. World Journal of

Emergency Surgery 2013 8:43.

\section{Submit your next manuscript to BioMed Central and take full advantage of:}

- Convenient online submission

- Thorough peer review

- No space constraints or color figure charges

- Immediate publication on acceptance

- Inclusion in PubMed, CAS, Scopus and Google Scholar

- Research which is freely available for redistribution 